\title{
Processes for Increasing the Concentration of Dissolved Oxygen in Stationary Waters
}

\author{
N. D. Albu ${ }^{1}$, N. Băran ${ }^{2} \&$ M. Constantin ${ }^{3}$ \\ ${ }^{1}$ Ph.D. Student, ${ }^{2}$ Professor Dr. Eng., ${ }^{3}$ Sl. Dr. Eng., Faculty of Mechanical Engineering and Mechatronics, Department of \\ Thermodynamics, Engines, Thermal and Refrigerating Equipment's, University Politehnica of Bucharest, Romania. \\ Email: i.mihaelaconstantin@gmail.com ${ }^{3}$ \\ DOI: http://doi.org/10.38177/ajast.2021.5106
}

Copyright: (C2021 N.D.Albu et al. This is an open access article distributed under the terms of the Creative Commons Attribution License, which permits unrestricted use, distribution, and reproduction in any medium, provided the original author and source are credited.

\section{ABSTRACT}

The paper presents four study versions: an aeration process and three stationary water oxygenation processes. In the aeration process, atmospheric air (21\% O2 and 79\% N2) is introduced into a pool of water. In the oxygenation process are introduced successively:

- A gaseous mixture of atmospheric air and a certain volume of oxygen taken from a cylinder.

- Low nitrogen air.

- A mixture of atmospheric air and ozone.

For the four versions, the experimental installations, the calculation results and the experimental obtained ones in case of the change of the dissolved oxygen concentration in the water are exposed. The electricity consumption for the four versions is analyzed at a certain time, when the initial concentration of dissolved oxygen in the water reaches the saturation concentration.

Keywords: Water oxygenation, Fine air bubble generator, Oxygen concentrator, Ozone generator.

\section{Introduction}

Increasing the dissolved oxygen content in water can be achieved in two ways [1] [2]:

I. By introducing atmospheric air $\left(21 \% \mathrm{O}_{2}+79 \% \mathrm{~N}_{2}\right)$ into water, a process called water aeration;

II. By introducing a gaseous mixture of air + oxygen in proportions other than $21 \% \mathrm{O}_{2}$; a process called water oxygenation; so:

a) Atmospheric air and oxygen are introduced from a cylinder; $\mathrm{O}_{2}=25 \%, 50 \%, 75 \%$ and $100 \%$.

b) Introduce $\mathrm{O}_{2}$ with low nitrogen content delivered by oxygen concentrators.

c) A gaseous mixture of air and ozone is introduced.

As a result, four versions will be studied in the paper:

- version I: air is introduced into the tank;

- version II: air + O2 from the cylinder is introduced into the tank;

- version III: low nitrogen air is introduced into the tank;

- version IV: a gaseous mixture of air + ozone is introduced into the tank.

Dissolved oxygen is needed for many life forms, including fish, invertebrates, bacteria and plants. These organisms use oxygen in their breath. Fish and crustaceans obtain oxygen for respiration through their gills, while plants and phytoplankton need dissolved oxygen for respiration when there is no light for photosynthesis. The amount of 


\section{AJAST}

Asian Journal of Applied Science and Technology (AJAST)

Volume 5, Issue 1, Pages 44-59, January-March 2021

dissolved oxygen required varies from one life form to another. Crabs, oysters and worms need minimal amounts of oxygen $(1 \div 6 \mathrm{mg} / \mathrm{dm} 3)$, while fish in shallow water need a higher level $\left(4 \div 15 \mathrm{mg} / \mathrm{dm}^{3}\right)$ [3]

In case of an excess of decomposition of organic matter (dead algae and other organisms) in a volume of water, the oxygen dissolved in the water is depleted faster. Dissolved oxygen enters water from the air or as a by-product of plants. From the air, oxygen can slowly diffuse to the surface water of the surrounding atmosphere, or it can be mixed rapidly by aeration, either natural or man-made. Aeration of water can be caused by wind (creating waves), waterfalls or other forms of running water. Dissolved oxygen is also a residual product of photosynthesis of phytoplankton, algae and other aquatic plants [3].

\section{Formulation of the Studied Problem}

By aeration of water is meant the process of transferring a gas into a liquid, namely atmospheric air into water.

The oxygen contained in the atmospheric air is $21 \%$ by volume; it is taken from the atmosphere and introduced into the water by means of dispersion elements which must ensure:

- a more uniform distribution of air bubbles in a volume of water: tank, basin, etc.

- the orifices of the dispersing device must be as small as possible, thus ensuring the immersion in water of air bubbles with the smallest diameter.

- the dispersing device must ensure an increased reliability of the installation and at the same time have a loss of air pressure as small as possible.

Aeration and oxygenation aim to increase the content of dissolved oxygen in water.

The term oxygenation is used when it is introduced into water:

- a mixture of air + oxygen from a gas tank;

- pure oxygen from a gas tank;

- low nitrogen air $\left(95 \% \mathrm{O}_{2}\right.$ and $\left.5 \% \mathrm{~N}_{2}\right)$ delivered by oxygen concentrators.

- a mixture of atmospheric air and ozone $\left(\mathrm{O}_{3}\right)$.

Depending on the principle of operation, aeration systems are classified into three classes [4] [5]:

A) Mechanical aeration installations;

B) Pneumatic aeration installations;

C) Mixed aeration installations.

All three classes aim to increase the oxygen content of the water (Figure 1). The figure shows that each water molecule consists of an oxygen atom coupled to two hydrogen atoms (yellow spheres). Oxygen dissolved in water is found by the water molecules. 


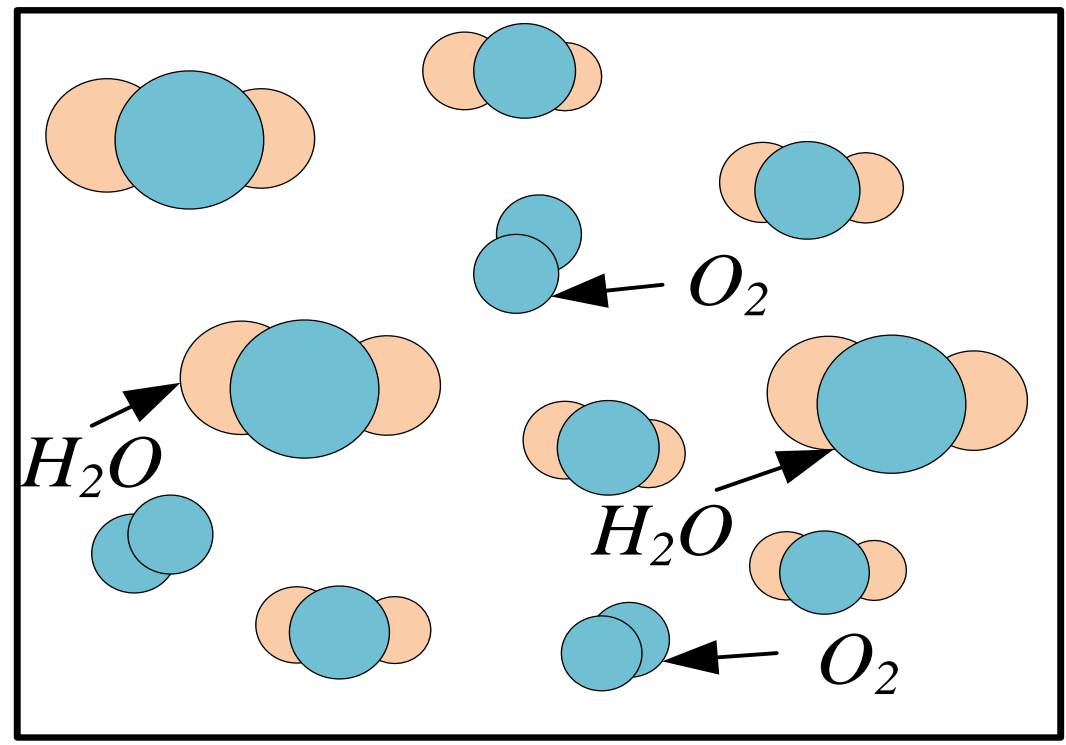

Fig.1. Oxygen Dissolved In Water (Blue Spheres)

The amount of oxygen dissolved in water depends on the following parameters [6] [7]:

- Atmospheric pressure;

- Water temperature;

- Water salinity;

- The degree of water turbulence.

The versions studied in this paper refer to a process of aeration and three processes of oxygenation of stationary water.

I. An aeration process: clean atmospheric air is introduced in the installation $\left(21 \% \mathrm{O}_{2}+79 \% \mathrm{~N}_{2}\right)$;

Three oxygenation processes, namely:

II. A gaseous mixture consisting of clean atmospheric air and a certain volume percentage of oxygen taken from a gas tank is introduced in the installation (here we have four cases: $25 \% \mathrm{O}_{2}+$ air, $50 \% \mathrm{O}_{2}+$ air, $75 \% \mathrm{O}_{2}+$ air, $100 \%$ $\left.\mathrm{O}_{2}\right)$.

III. Air with a low nitrogen content $\left(95 \% \mathrm{O}_{2}+5 \% \mathrm{~N}_{2}\right)$ delivered by devices called oxygen concentrators is introduced into the installation.

IV. A mixture of atmospheric air and ozone $\left(\mathrm{O}_{3}\right)$ is introduced into the installation; ozone is delivered by an ozone generator.

As the composition of the gas mixtures will be different, the experiment time will be different and obviously the energy consumption will be different.

For all four versions the initial data will be the same: 
-Volume air flow rate: $\dot{V}=0.6 \mathrm{~m}^{3} / \mathrm{h}$;

-Compressed air pressure: $\mathrm{H}=583 \mathrm{~mm} \mathrm{H}_{2} \mathrm{O}$;

-Hydrostatic load: $\mathrm{H}=500 \mathrm{~mm} \mathrm{H2O}$;

-Water and air temperatures: $t=24^{\circ} \mathrm{C}$;

-Initial concentration of dissolved oxygen: $\left(C_{O 2}\right)_{0}=5.84 \mathrm{mg} / \mathrm{dm}^{3}$.

During the experimental researches it will be followed:

-What is the consumption of electricity for the concentration of dissolved oxygen in water to increase from an initial value $\mathrm{C}_{0}\left(\mathrm{mg} \mathrm{O}_{2} / \mathrm{dm}^{3}\right)$ to saturation $\mathrm{C}_{s}\left(\mathrm{mg} \mathrm{O}_{2} / \mathrm{dm}^{3}\right)$.

-Knowing that the saturation values $\left(C_{s}\right)$ may be different, the elapsed time will be measured till $\left(C_{O 2}\right)_{0}$ reaches $C_{s}$. -The equipment's and devices during $\Delta \tau$ will consume a certain power $\left(P_{i}[W]\right)$.

For each version, according to certain measurements, it will be determined comparatively in two ways:

$\mathrm{E}_{\mathrm{i}}=\mathrm{P}_{\mathrm{i}} \cdot \Delta \tau[\mathrm{kWh}]$

The consumed energy $\mathrm{E}_{\mathrm{el}}[\mathrm{kWh}]$ will be read on the electric meter.

The values obtained on the two paths must be equal to $E_{i}=E_{e l}[k W h]$. The results for the four versions will be compared and it will be decided which is the most economical.

\section{Scheme of the Experimental Installation for Each Studied Version}

3.1. Version I: clean atmospheric air is introduced into the installation $\left(21 \% \mathrm{O}_{2}+79 \% \mathrm{~N}_{2}\right)$.

3.2. Version II: a mixture of atmospheric air and oxygen from a gas tank is introduced in the installation (air $+25 \%$ $\mathrm{O}_{2}$, air $+50 \% \mathrm{O}_{2}$, air $\left.+75 \% \mathrm{O}_{2}, 0+100 \% \mathrm{O}_{2}\right)$.

3.3. Version III: low nitrogen-containing air $\left(95 \% \mathrm{O}_{2}+5 \% \mathrm{~N}_{2}\right)$ is introduced into the installation.

3.4. Version IV: a gaseous mixture of atmospheric air and ozone $\left(\mathrm{O}_{3}\right)$ is introduced into the installation.

Within each installation the aim will be to increase the dissolved oxygen concentration in the water depending on:

-the composition of the gas introduced into the water;

-duration of experience.

It is specified that the values of $\left(\mathrm{C}_{\mathrm{O} 2}\right)_{0}$ and $\mathrm{H}$, must be the same for all versions.

\subsection{Version I: Clean Atmospheric Air is Introduced into the Installation $\left(21 \% \mathrm{O}_{2}+79 \% \mathrm{~N}_{2}\right)$}

The scheme of the installation is shown in figure 2 . 


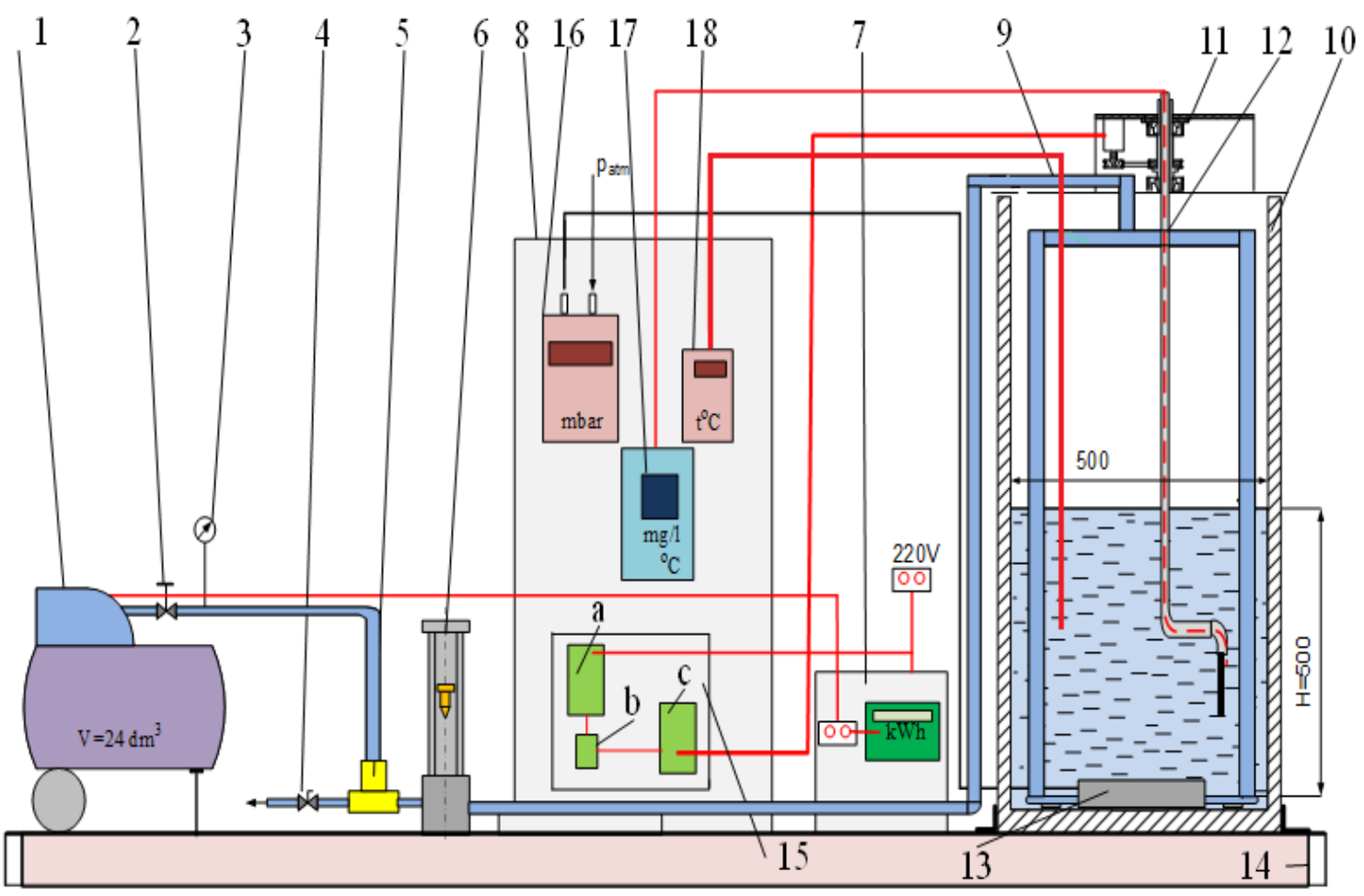

Fig.2. Scheme of the Experimental Installation for Researches on Water Oxygenation

1 - ELECTRO COMPRESSOR WITH AIR TANK; 2 - PRESSURE REDUCER; 3 - MANOMETER;

4 - CONNECTION FOR EVACUATING AIR INTO THE ATMOSPHERE; 5 - T-JOINT;

6 - ROTAMETER; 7 - ELECTRICAL PANEL; 8 - PANEL WITH MEASURING DEVICES; 9 - PIPE FOR TRANSPORTING COMPRESSED AIR TO THE BUBBLE GENERATOR; 10 - WATER TANK; 11 - MECHANISM OF ACTUATION OF THE PROBE; 12 - OXYGENOMETER PROBE; 13 - BUBBLE GENERATOR; 14 - SUPPORT FOR INSTALLATION; 15 - CONTROL ELECTRONICS: A - POWER SUPPLY, B - SWITCH, C - CONTROL ELEMENT, 16 - DIGITAL MANOMETER; 17 - OXYGENOMETER; 18 - DIGITAL THERMOMETER

The installation consists of:

-An electro compressor that compresses the air and sends it to the compressor tank.

-A pressure reducer.

-Compressed air plastic pipes for the air delivery, with inner diameter $\emptyset=15 \mathrm{~mm}$ and a wall thickness of $2 \mathrm{~mm}$; they supply the microbubble generator with air and ensure the evacuation of the surplus air delivered by the compressor to the atmosphere.

-Aeration tank made of plexiglass plates with a thickness of $5 \mathrm{~mm}$, having the size of $0.5 \cdot 0.5 \cdot 1.6 \mathrm{~m}$.

-The microbubble generator (MBG) was subjected to tests in an experimental installation built in the laboratories of the University POLITEHNICA of Bucharest. The orifices in the plate with $\mathrm{d}_{0}=0.1 \mathrm{~mm}$ were made using a C.N.C. (Computer Numerical Center) which has a special machine KERN type for micro processing [8] [9]. 
-The mechanism of action of the oxygenometer probe.

-Table with control electronics.

-Devices for measuring the flow rate, pressure, temperature and the dissolved oxygen concentration in water.

This concentration is measured every 15 minutes for two hours; from previous experiments in two hours or less from $\left(\mathrm{C}_{\mathrm{O} 2}\right)_{0}$ reaches $\mathrm{C}_{\mathrm{s}}$.

\subsection{Version II: A Mixture of Atmospheric Air and Oxygen from a Cylinder is Introduced into the Installation}

The scheme of the installation is shown in figure 3.

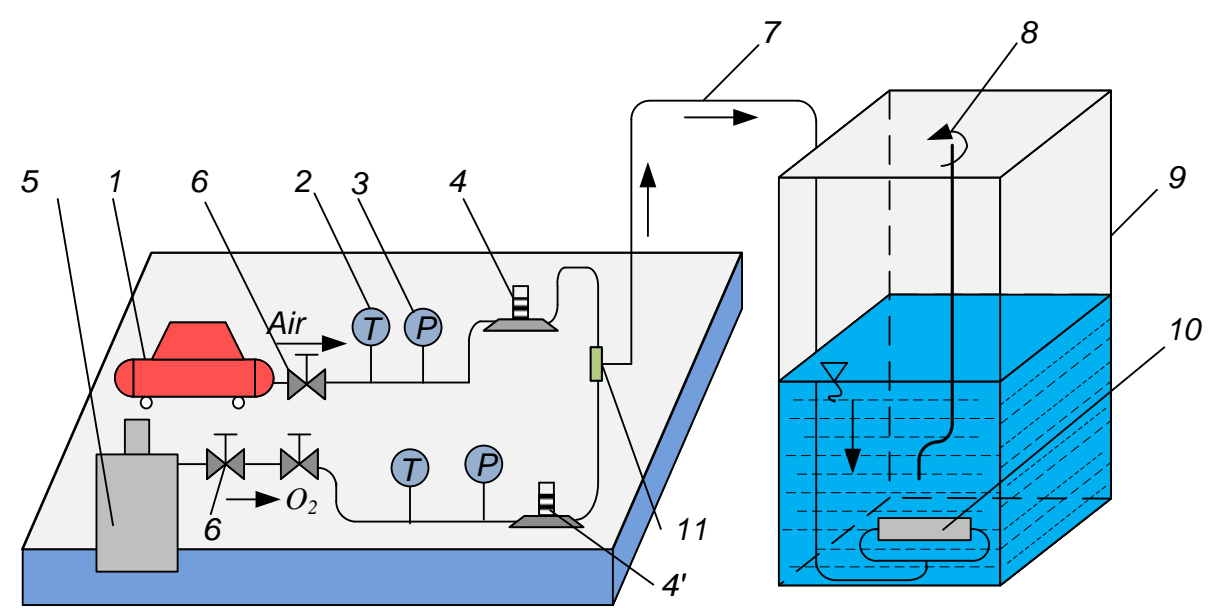

Fig.3. Scheme of the Installation of the Introduction of a Mixture of Atmospheric Air and Oxygen in the Microbubble Generator

1 - AIR ELECTRO COMPRESSOR; 2 - GAS TEMPERATURE MEASURING DEVICE WITH DIGITAL INDICATION; 3 - GAS PRESSURE MEASURING DEVICE WITH DIGITAL INDICATION; 4, 4 '- ROTAMETER; 5 - OXYGEN CYLINDER: P = 120 BAR; 6 - PRESSURE REDUCER; 7 - AIR + OXYGEN SUPPLY PIPE OF THE MICROBUBBLE GENERATOR; 8 - OXYGENOMETER PROBE; 9 - WATER TANK; 10 - MICROBUBBLE GENERATOR; 11 - MIXING CHAMBER OF THE TWO GAS CURRENTS

The working parameters of the installation are the same: $\dot{V}=600 \mathrm{dm}^{3} / h, \mathrm{H}=583 \mathrm{mmH}_{2} \mathrm{O} ; \tau=2 \mathrm{~h}$.

Atmospheric air and oxygen delivered from the cylinder are measured separately with rotameters 4 and 4'.

A gas flow rate $\dot{V}=600 \mathrm{dm}^{3} / \mathrm{h}$ is successively introduced in the water tank, composed of:

Version II, case 1: $\dot{V}_{O_{2}}=150 \mathrm{dm}^{3} / h$; and $\dot{V}_{\text {air }}=450 \mathrm{dm}^{3} / \mathrm{h}$;

Version II, case 2: $\dot{V}_{\mathrm{O}_{2}}=350 \mathrm{dm}^{3} / \mathrm{h}$; and $\dot{V}_{\text {air }}=300 \mathrm{dm}^{3} / \mathrm{h}$;

Version II, case 3: $\dot{V}_{\mathrm{O}_{2}}=450 \mathrm{dm}^{3} / \mathrm{h}$; and $\dot{V}_{\text {air }}=150 \mathrm{dm}^{3} / \mathrm{h}$;

Version II, case 4: $\dot{V}_{O_{2}}=600 \mathrm{dm}^{3} / \mathrm{h}$; and $\dot{V}_{\text {air }}=0 \mathrm{dm}^{3} / \mathrm{h}$. 
For version II, in cases 1,2,3,4 it is observed that the introduced gas flow rate (the sum between atmospheric air and oxygen in the gas tank is the same) is the same.

1. $\dot{V}_{O_{2}}=150 \mathrm{dm}^{3} / \mathrm{h}+\dot{V}_{\text {air }}=450 \mathrm{dm}^{3} / \mathrm{h}=600 \mathrm{dm}^{3} / \mathrm{h}$

2. $\dot{V}_{O_{2}}=300 \mathrm{dm}^{3} / \mathrm{h}+\dot{V}_{\text {air }}=300 \mathrm{dm}^{3} / \mathrm{h}=600 \mathrm{dm}^{3} / \mathrm{h}$

3. $\dot{V}_{O_{2}}=450 \mathrm{dm}^{3} / \mathrm{h}+\dot{V}_{\text {air }}=150 \mathrm{dm}^{3} / \mathrm{h}=600 \mathrm{dm}^{3} / \mathrm{h}$

4. $\dot{V}_{O_{2}}=600 \mathrm{dm}^{3} / \mathrm{h}+\dot{V}_{\text {air }}=0 \mathrm{dm}^{3} / \mathrm{h}=600 \mathrm{dm}^{3} / \mathrm{h}$

After the measurements in each case, drain the water from the tank and introduce $V_{H_{2} O}=0.125 \mathrm{~m}^{3}$ so that the hydrostatic load $\mathrm{H}$ is always $\mathrm{H}=500 \mathrm{mmH}_{2} \mathrm{O}$.

\subsection{Version III: Low Nitrogen Air is Introduced into the Installation $\left(95 \% \mathrm{O}_{2}+5 \% \mathrm{~N}_{2}\right)$}

The scheme of the installation is shown in figure 4.

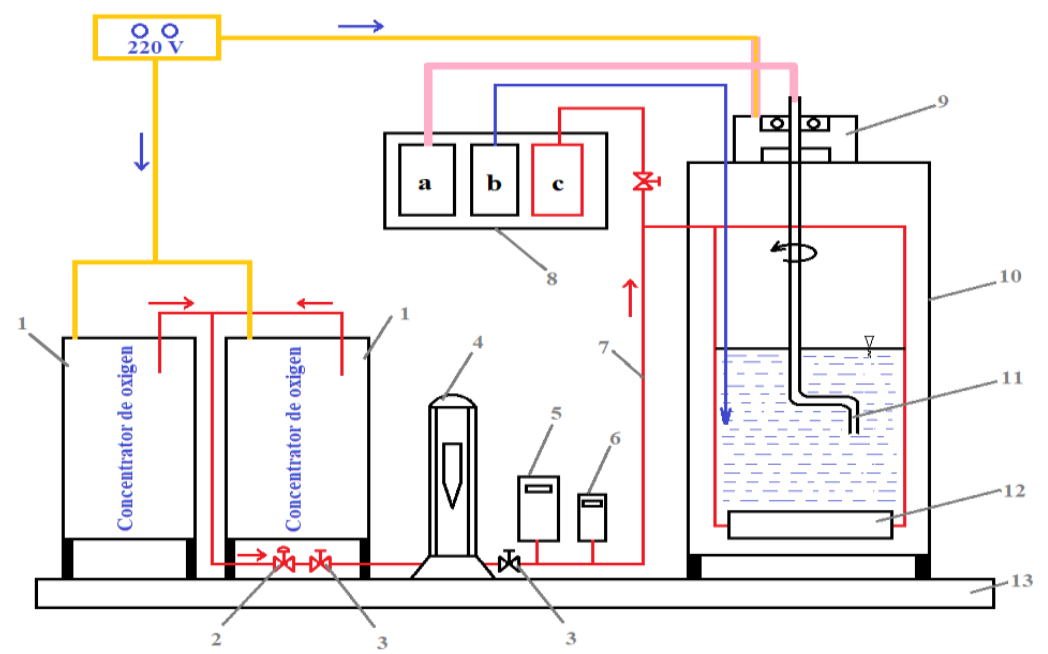

Fig.4. Scheme of the Installation for Oxygenation of Water with Low Nitrogen Content

1 - OXYGEN CONCENTRATORS; 2 - PRESSURE REGULATOR; 3 - VALVES WITH VALVE; 4 - ROTAMETER; 5- MANOMETER WITH DIGITAL INDICATION; 6 - THERMOMETER WITH DIGITAL INDICATION; 7 - COMPRESSED AIR PIPE; 8 - PANEL WITH DEVICES; A - OXYGENOMETER; B - THERMOMETER; C - MANOMETER; 9 - ELECTROMECHANICAL MECHANISM FOR ACTUATING THE OXYGENOMETER PROBE; 10 - WATER TANKS; 11 - OXYGENOMETER PROBE; 12 - FINE BUBBLE GENERATOR; 13 - EXPERIMENTAL INSTALLATION SUPPORT PLATE

The oxygen needed for the water oxygenation process is obtained by separating it from the air by adsorption and retention of other gases $\left(\mathrm{N}_{2}, \mathrm{CO}_{2}\right.$, etc.) using substances called zeolites. Following this process, gaseous oxygen is obtained with a purity of $95 \% \mathrm{O}_{2}$, and a pressure higher than atmospheric pressure [10] [11]. Each concentrator has a rotameter for measuring gas flow rate; the two PLATINUM type concentrators deliver together $600 \mathrm{dm}^{3} / \mathrm{h}$ of gas. 


\subsection{Version IV: A Gaseous Mixture of Atmospheric Air and $\mathrm{Ozone}\left(\mathrm{O}_{3}\right)$ is Introduced into the Installation}

The experimental installation for water ozonation was carried out within the University Politehnica of Bucharest, the Faculty of Mechanical and Mechatronics Engineering, the Department of Thermotechnics, Engines, Thermal and Refrigerating Equipment's, having the principal scheme presented in figure 5.

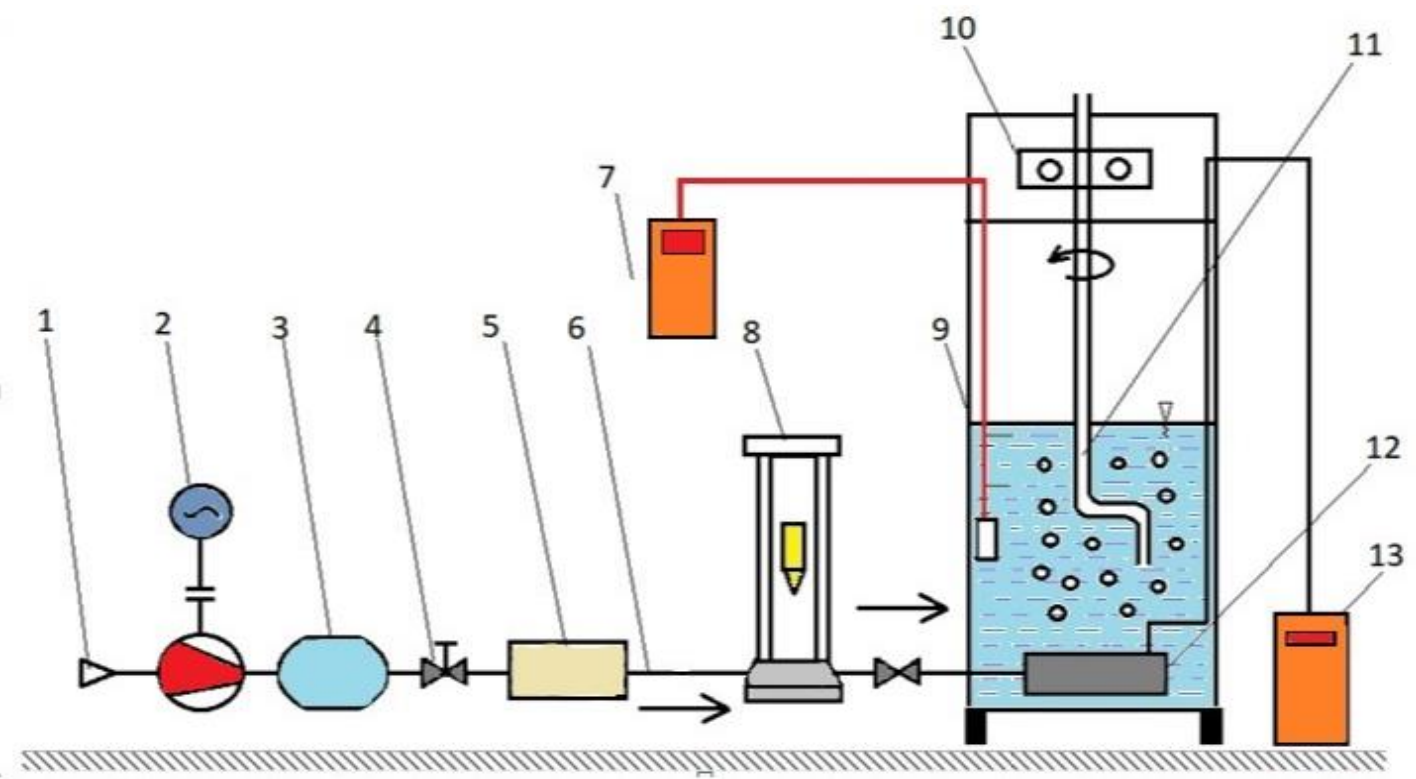

Fig.5. Scheme of the Installation for Experimental Researches on the Use of Ozone in Water Oxygenation

1 - AIR FILTER; 2 - ELECTRO COMPRESSOR; 3 - COMPRESSED AIR TANK; 4 - PRESSURE REDUCER; 5 - OZONE GENERATOR; 6 - PIPE; 7 - THERMOMETER WITH DIGITAL INDICATION; 8 - ROTAMETER; 9 - WATER TANK; 10 - MECHANISM FOR ROTATING THE OXYGENOMETER PROBE IN WATER; 11 - OXYGENOMETER PROBE; 12 - FINE BUBBLE GENERATOR; 13 - MANOMETER WITH DIGITAL INDICATION

The designing and constructing the experimental installation started from the purpose of the researches, namely the experimental determination of the variation of the dissolved oxygen concentration in the water as a function of time.

An experimental ozone generator type TCB-300O_3 was used for the experimental researches; the mixture of air and ozone being transferred to the water by means of a fine bubble generator.

Ozone generators (figure 6) $\mathrm{TCB}_{300 \mathrm{O}_{3}}$, can be used for a wide range of applications (from domestic to municipal), both for air, drinking water and wastewater.

Ozone generators are intended to produce a mixture of air or oxygen with ozone suitable for several types of processes such as [12] [13] [14]:

-Drinking water treatment

-Swimming pool water treatment

-Water purification 


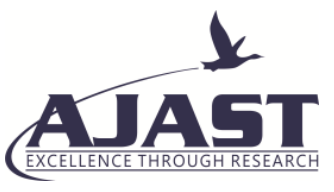

Asian Journal of Applied Science and Technology (AJAST)

Volume 5, Issue 1, Pages 44-59, January-March 2021

-Water cooling

-Disinfection

-The oxidation process in industry

Figure 6 shows a horizontal plan view of the ozone generator.

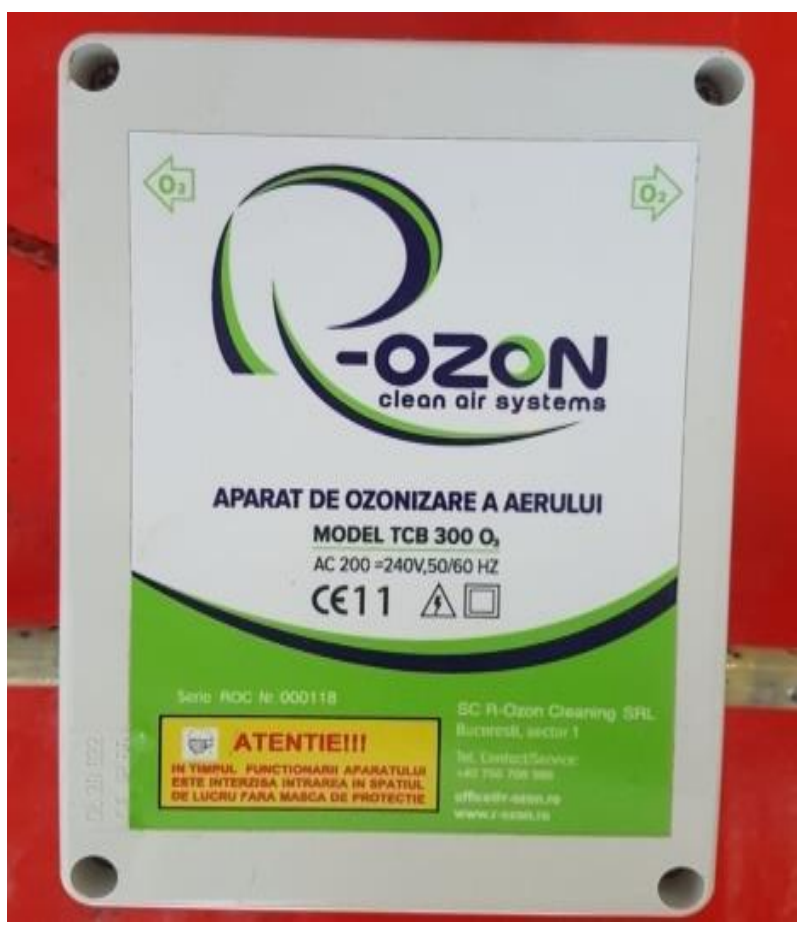

Fig.6. Ozone Generator

\section{Specification of the Initial Composition and Saturation Concentration for Each Calculation Version}

The theoretical study starts from the following hypotheses:

-air flow rate or mixture flow rate (air + oxygen), (low nitrogen content) is the same and equal to $600 \mathrm{dm}^{3} / \mathrm{h}$; -pressure of the gas mixture $573 \mathrm{~mm} \mathrm{H}_{2} \mathrm{O}$;

-the height of the water layer remains constant: $\mathrm{H}=500 \mathrm{~mm} \mathrm{H}_{2} \mathrm{O}$;

-work time, i.e. duration of an experiment: $\tau=120$ minutes;

-the water temperature remains the same;

-the value of the initial concentration of the water from the network is intended to be the same.

The following versions of introduction of gas mixtures into water are theoretically analyzed:

-Clean atmospheric air $\left(21 \% \mathrm{O}_{2}+79 \% \mathrm{~N}_{2}\right)$;

-Gas mixture: air + gaseous oxygen in the cylinder $\mathrm{r}_{\mathrm{O} 2}=25 \%, \mathrm{r}_{\mathrm{O} 2}=50 \%, \mathrm{r}_{\mathrm{O} 2}=75 \%, \mathrm{r}_{\mathrm{O} 2}=100 \%$ );

-Air with low nitrogen content;

-Mixture of air and ozone. 


\section{AJAST}

Asian Journal of Applied Science and Technology (AJAST)

Volume 5, Issue 1, Pages 44-59, January-March 2021

For the four gas mixtures, some input data in the calculation program are the same. It is specified that the value of oxygen concentration at saturation is different in versions I, II, III and IV.

The air contains $21 \% \mathrm{O}_{2}$ and $79 \% \mathrm{~N}_{2}$, so the amount of nitrogen decreases the results of water oxygenation; compressing the air consumes a large amount of energy, which ultimately has a low efficiency.

The equation that specifies the rate of oxygen transfer to water [15] [16].

$$
\frac{d C}{d \tau}=a \cdot k_{L} \cdot\left(C_{s}-C_{0}\right) \rightarrow(\mathbf{1})
$$

indicates that the rate of oxygen transfer to water is directly proportional to the oxygen deficiency $\mathrm{D}$ relative to saturation $\mathrm{D}=\mathrm{C}_{\mathrm{S}}-\mathrm{C}_{0}$. The value of the $\mathrm{C}_{0}$ concentration is given, measured, i.e. it is fixed.

For air $\left(21 \% \mathrm{O}_{2}+79 \% \mathrm{~N}_{2}\right)$ at $\mathrm{t}=20{ }^{\circ} \mathrm{C}$ and pressure $\mathrm{p}=760 \mathrm{~mm} \mathrm{Hg}$ a saturation concentration $\mathrm{C}_{\mathrm{s}}=9.02 \mathrm{mgO}_{2} / \mathrm{dm}^{3}$ will result. If $\mathrm{C}_{0}=2 \mathrm{mg} \mathrm{O}_{2} / \mathrm{dm}^{3}$ then the oxygen deficiency is:

$$
D_{A}=C_{S}-C_{0}=9.02-2 \approx 7 m g O_{2} / d m^{3} \rightarrow(2)
$$

The correction of the saturation concentration according to the composition of the gas used is carried out as follows: if oxygen-enriched or pure oxygen-rich air is used for oxygenation, the saturation concentration is corrected by the factor "k" according to the relation:

$$
C_{s}=C_{s, a e r} \cdot \frac{k \%}{21 \%} \rightarrow(3)
$$

where $\mathrm{k} \%$ represents the volume concentration of oxygen in the diffusing gas.

For $\mathrm{t}=20^{\circ} \mathrm{C}$ and $\mathrm{p}=760$ torr, for air the saturation concentration is $\mathrm{C}_{\mathrm{s}, \mathrm{ar}}=9.02 \mathrm{mg} \mathrm{O}_{2} / \mathrm{dm}^{3}$.

For different values of the gas mixture between air and pure oxygen the following cases result:

-for $\mathrm{k}=25 \%$, version II results in case 1 :

$C_{s, 25}=C_{s, a i r} \cdot k \% /(21 \%)=9.02 \cdot 25 / 21=10.73 \mathrm{mgO}_{2} / \mathrm{dm}^{3} \rightarrow$

-for $\mathrm{k}=50 \%$ the version II results in case 2 :

$C_{s, 50}=C_{s, a i r} \cdot k \% /(21 \%)=9.02 \cdot 50 / 21=21.476 m g O_{2} / d^{3} \rightarrow(5)$

-for $\mathrm{k}=75 \%$, version II results in case 3 :

$C_{s, 75}=C_{s, a i r} \cdot k \% /(21 \%)=9.02 \cdot 75 / 21=32.214 m g O_{2} / d^{3} \rightarrow(6)$

-for $\mathrm{k}=100 \%$, version II results in case 4 :

$$
C_{s, 100}=C_{s, a i r} \cdot k \% /(21 \%)=9.02 \cdot 100 / 21=43 \mathrm{mgO}_{2} / \mathrm{dm}^{3} \rightarrow(7)
$$

The above values are useful as initial data of the calculation program. 


\section{AJAST}

Asian Journal of Applied Science and Technology (AJAST)

Volume 5, Issue 1, Pages 44-59, January-March 2021

Here reference is made only to version II, i.e. a mixture of atmospheric air + oxygen from the cylinder is introduced into the tank. It is considered a volumetric flow rate of $600 \mathrm{dm}^{3} / \mathrm{h}$ formed by different gas mixtures; this flow rate results from the gas mixing, but each flow rate will be measured separately. This flow rate remains constant, but will have a given composition in 4 cases; in each case the volume participation $\left(r_{i}\right)$ of the oxygen flow rate into the air changes, resulting in a mixture of air + oxygen which is introduced into the water tank.

Table 1. $C_{S}$ Saturation Values for the Four Cases of Version II

\begin{tabular}{|c|c|c|c|c|c|c|}
\hline Nr.crt & $\dot{V}\left[\frac{d m^{3}}{h}\right]$ & $\mathrm{V}$ aer $\left[\frac{d m^{3}}{h}\right]$ & $r_{i, O_{2}}$ & $V_{O 2}\left[\frac{d m^{3}}{h}\right]$ & $C_{0}\left[\frac{m g}{d m^{3}}\right]$ & $C_{s}\left[\frac{m g}{d m^{3}}\right]$ \\
\hline 1. & 600 & 450 & 25 & 150 & 5.84 & 10.73 \\
\hline 2. & 600 & 300 & 50 & 300 & 5.84 & 21.46 \\
\hline 3. & 600 & 150 & 75 & 450 & 5.84 & 32.21 \\
\hline 4. & 600 & 0 & 100 & 600 & 5.84 & 43.00 \\
\hline
\end{tabular}

Table 1 shows that the value of dissolved oxygen concentration in water changes depending on the composition of the gas introduced in water. A calculation program [18] was developed to determine the change in the dissolved oxygen concentration in water, as a function of time. Subsequent experimental researches were performed. The results obtained after running the calculation program and the results of the experimental researches are presented in Figure 7.

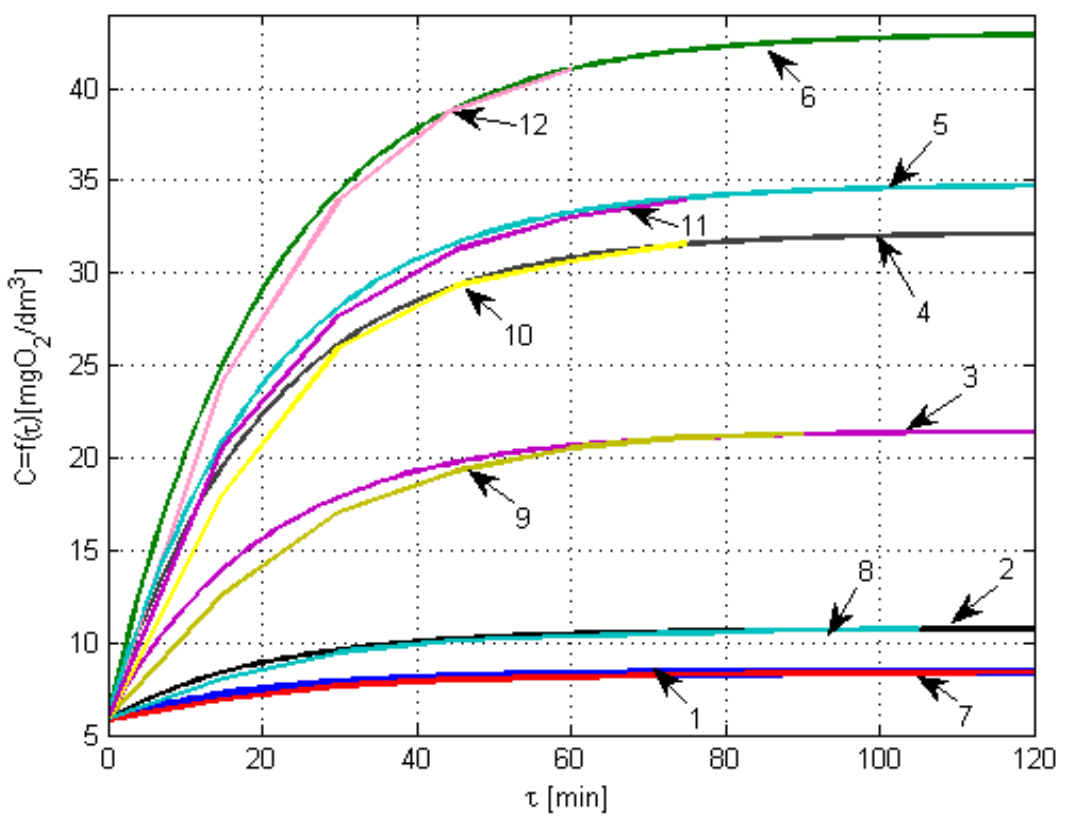

Fig.7. Variation in the Dissolved Oxygen Concentration in Water in Time for the Three Versions and the Four Cases of Version II

CURVES DRAWN BASED ON THEORETICAL DATA: 1 - FOR ATMOSPHERIC AIR; 2 - AIR + OXYGEN FROM THE CYLINDER $\left(150 \mathrm{dm}^{3} / \mathrm{h}\right) ; 3$ - AIR + OXYGEN FROM THE CYLINDER $\left(300 \mathrm{dm}^{3} / \mathrm{h}\right) ; 4$ - AIR + 
OXYGEN FROM THE CYLINDER (450 $\left.\mathrm{dm}^{3} / \mathrm{h}\right) ; 5$ - FOR AIR WITH LOW NITROGEN CONTENT; 6 - AIR + OXYGEN FROM THE CYLINDER $\left(600 \mathrm{dm}^{3} / \mathrm{h}\right)$;

CURVES DRAWN BASED ON EXPERIMENTAL DATA: 7 - FOR ATMOSPHERIC AIR; 8 - AIR + OXYGEN FROM THE CYLINDER $\left(150 \mathrm{dm}^{3} / \mathrm{h}\right) ; 9$ - AIR + OXYGEN FROM THE CYLINDER $\left(300 \mathrm{dm}^{3} / \mathrm{h}\right) ; 10$ - AIR + OXYGEN FROM THE CYLINDER (450 $\left.\mathrm{dm}^{3} / \mathrm{h}\right) ; 11$ - FOR LOW NITROGEN AIR; 12 - AIR + OXYGEN FROM THE CYLINDER $\left(600 \mathrm{dm}^{3} / \mathrm{h}\right)$

Figure 7 shows a good concordance between theoretical data and data experimentally obtained. Obviously, the $\mathrm{C}_{\mathrm{s}}$ value is reached the fastest when pure oxygen is introduced into the water.

\section{Determination of Energy Consumption for Version I, Version II (With Four Cases), Versions III \& IV}

\section{Version I}

For version I, $0.6 \mathrm{~m}^{3} / \mathrm{h}$ of atmospheric air is introduced into the water. Energy $\mathrm{E}$ is the product of the consumed power $\mathrm{P}_{\mathrm{I}}[\mathrm{kW}]$ and the operating time of the installation $\tau[\mathrm{h}]$.

For version I it is obtained:

$$
E_{I}=P_{t} \cdot \tau_{f, I}[k W h] \rightarrow(\mathbf{8})
$$

The power $\mathrm{P}_{\mathrm{t}}$ is the power required to drive the compressor in a single-cylinder gear.

$$
P t=\frac{n}{n-1} \cdot p_{1} \cdot \dot{V}_{a} \cdot\left(\varepsilon^{\frac{n-1}{n}}-1\right) \cdot \frac{1}{10^{3}}[k W] \rightarrow(\mathbf{9})
$$

Where:

$-\mathrm{n}$ is the polytropic exponent $\mathrm{n}=1.3$;

$-\mathrm{p}_{1}$ - suction pressure $\mathrm{p}_{1}=1$ bar;

$\dot{V}_{a}$ - aspirated flow rate $=0.6 / 3600\left[\mathrm{~m}^{3} / \mathrm{s}\right] ;$

$\varepsilon$ - compression ratio $\varepsilon=1.5$.

$$
P_{t}=\frac{1.3}{1.3-1} \cdot 10^{5} \cdot \frac{0.6}{3600} \cdot\left(1.5^{\frac{1.3-1}{1.3}}-1\right) \cdot \frac{1}{10^{3}}[k W] \rightarrow(\mathbf{1 0})
$$

$P_{t}=0.00705=7 \cdot 10^{-3}[\mathrm{~kW}] \rightarrow(\mathbf{1 1})$

Admitting a efficiency of the $\eta_{\text {agr }}$, compressor + electric drive motor, of 0.5 , results in the real drive power:

$$
P_{I}=\frac{P_{t}}{\eta_{a g r}}=\frac{7 \cdot 10^{-3}}{0.5}=14 \cdot 10^{-3}[\mathrm{~kW}] \rightarrow(\mathbf{1 2})
$$

The operating time of the installation is two hours, so the mechanical energy consumed to reach from $\mathrm{C}_{0}$ to $\mathrm{C}_{\mathrm{s}}$ : 


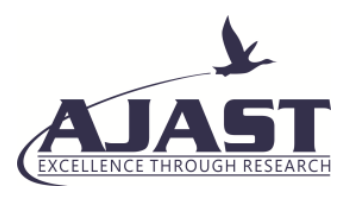

Asian Journal of Applied Science and Technology (AJAST)

Volume 5, Issue 1, Pages 44-59, January-March 2021

$E_{I}=P_{I} \cdot \tau_{I}=14 \cdot 10^{-3} \cdot 2=28 \cdot 10^{-3}[\mathrm{kWh}]$

It is known that the average efficiency of a coal-fired power plant is 30\%, as a result of the electricity absorbed from the electricity network in the case of the first variant will be:

$E_{I, e l}=E_{I} / \eta_{C T E}=0.028 / 0.3=0.0933[\mathrm{kWh}] \rightarrow \mathbf{( 1 4 )}$

\section{Version II}

For the four cases from version II the volume of gas aspirated by the compressor will be:

$\dot{V}=\frac{0.6}{3600} \mathrm{~m}^{3} / \mathrm{s}$ and the compression ratio is $\varepsilon=1.5$, the same as in version I.

As a result, the electricity absorbed from the grid will be the same:

$$
E_{I I, e l}=E_{I} / \eta_{C T E}=0.028 / 0.3=0.0933[\mathrm{kWh}] \rightarrow(\mathbf{1 5})
$$

\section{Version III}

The PLATINUM type oxygen concentrator (2 pieces) used in the installation provides $300 \mathrm{dm}^{3} / \mathrm{h}$ of $\mathrm{O}_{2}$, so both work with $600 \mathrm{dm}^{3} / \mathrm{h}$ of $\mathrm{O}_{2}$.

From the technical data of the oxygen concentrator, it results that the maximum pressure at the outlet of the compressed gas is 0.35 bar, so the compression ratio compared to version I will be:

$\varepsilon^{\frac{n-1}{n}} \rightarrow \varepsilon=1.35^{\frac{1.3-1}{1.3}}<1.5^{\frac{1.3-1}{1.3}} \Leftrightarrow 1.35^{0.23}<1.5^{0.23} \rightarrow(\mathbf{1 6})$

As a result, the electricity consumed from the network will be lower:

$E_{I I I}=1.071 / 1.007=0.09756[k W] \rightarrow(\mathbf{1 7})$

$E_{\text {III }}=0.0935 \cdot 0.09756[k W h] \rightarrow(\mathbf{1 8})$

$E_{I I I}<E_{I} \rightarrow(\mathbf{1 9})$

\section{Version IV}

Air + ozone is introduced into the installation; the air flow rate and air pressure are the same as in version I; here appears an electricity consumption of the ozone generator.

To the value $\mathrm{E}_{\mathrm{I}, \mathrm{el}}=0.0933[\mathrm{kWh}]$ is added the electricity consumption of the ozone generator; from the package leaflet $\mathrm{E}_{\mathrm{ozon}}=0.04[\mathrm{kWh}]$.

$E_{I V}=E_{I, e l}+E_{\text {ozone }}=0.0933+0.04=0.1333[k W h] \rightarrow(\mathbf{2 0})$

From the preceding paragraphs, it follows: 


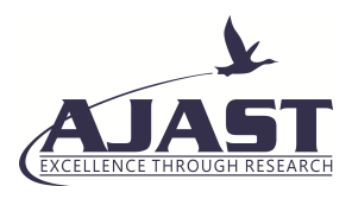

Asian Journal of Applied Science and Technology (AJAST)

Volume 5, Issue 1, Pages 44-59, January-March 2021

Table 2. Theoretically Calculated Values

\begin{tabular}{|c|c|c|c|c|c|c|c|}
\hline No & Introduced gas & $\begin{array}{c}\text { Operating } \\
\text { timeC }_{0} \rightarrow \mathrm{C}_{\mathrm{s}} \\
{[\tau]}\end{array}$ & $\begin{array}{c}\mathrm{C}_{\mathrm{s}} \text { value } \\
{\left[\mathrm{mgO}_{2} / \mathrm{dm}^{3}\right]}\end{array}$ & $\begin{array}{l}\text { Time to } \\
\text { reach } C_{s}\end{array}$ & $\begin{array}{c}\text { Electricity } \\
\text { consumed } \\
{[\mathrm{kWh}]}\end{array}$ & $\begin{array}{l}\text { Price } \\
\text { lei/kWh }\end{array}$ & $\begin{array}{l}\text { Total } \\
\text { cost } \\
\text { [lei] }\end{array}$ \\
\hline I & Atmospheric air & 2 & 8.40 & $2 \mathrm{~h}$ & 0.0933 & 0.633 & 0.059 \\
\hline \multirow{4}{*}{ II } & $\begin{array}{c}\text { Case } 1 \\
\text { air }+25 \% \mathrm{O}_{2}\end{array}$ & 2 & 10.73 & $15^{\prime}$ & 0.0933 & 0.633 & 0.059 \\
\hline & $\begin{array}{c}\text { Case } 2 \\
\text { air }+50 \% \mathrm{O}_{2}\end{array}$ & 2 & 21.46 & 5 , & 0.0933 & 0.633 & 0.059 \\
\hline & $\begin{array}{c}\text { Case } 3 \\
\text { air }+75 \% \mathrm{O}_{2}\end{array}$ & 2 & 32.21 & 3 ' & 0.0933 & 0.633 & 0.059 \\
\hline & $\begin{array}{c}\text { Case } 4 \\
\text { air }+100 \% \mathrm{O}_{2}\end{array}$ & 2 & 43.00 & 2 ' & 0.0933 & 0.633 & 0.059 \\
\hline III & $\begin{array}{c}\text { Low nitrogen air } \\
\qquad(95 \%)\end{array}$ & 2 & 34.80 & $2,5^{\prime}$ & 0.0900 & 0.633 & 0.056 \\
\hline IV & Air + ozone & 2 & 8.98 & 75 , & 0.133 & 0.633 & 0.084 \\
\hline
\end{tabular}

From table 2 one can observe that following theoretical calculations the most advantageous method is version III.

\section{Conclusion}

From the analysis of the four versions studied to increase the dissolved oxygen concentration in water, namely:

-Version I: Introduction of atmospheric air into water;

- Version II: Introduction of a gaseous mixture of air and oxygen from a gas tank;

- Version III: Introduction of air with reduced nitrogen content;

- Version IV: Introduction of a mixture of atmospheric air and ozone $\left(\mathrm{O}_{3}\right)$.

there is the same degree of difficulty in their practical realization.

From the energy analysis of the four performed versions, it was found that the most favourable is version III because the transport of nitrogen from the suction to the discharge is eliminated, i.e. a gas that is not related to the oxygenation of the waters is eliminated.

The idea of separating nitrogen from $\mathrm{O}_{2}$ is very good. 


\section{Declarations}

\section{Source of Funding}

This research did not receive any specific grant from funding agencies in the public, commercial, or not-for-profit sectors.

\section{Competing Interests Statement}

The authors declare no competing financial, professional and personal interests.

\section{Consent for publication}

We declare that we consented for the publication of this research work.

\section{Code availability}

The programming code that we have used for this research is available and authors are willing to share when it is required.

\section{References}

[1] S. Stoianovici, D. Robescu, D. Stamatoiu, Calculul şi construcţia echipamentelor de oxigenare a apelor, Editura CERES, Bucureşti, 1985.

[2] D. Robescu, D. L. Robescu, Procedee, instalații și echipamente pentru epurarea fizică a apelor uzate, Ed. BREN, Bucureşti,1999.

[3] E. B. Tănase, Influența compoziției gazului insuflat în apă asupra conținutului de oxigen dizolvat, Teză de doctorat, Universitatea Politehnica din Bucureşti, Facultatea de Inginerie Mecanică şi Mecatronică, 2017.

[4] D. L. Robescu, F. Stroe, A. Presura, D. Robescu, Tehnici de epurare a apelor uzate, Editura Tehnică, București, 2011.

[5] M. K. Stenstrom, D. Rosso, Aeration, University of California - Los Angeles, 2010

[6] G. Oprina, I. Pincovschi, Ghe. Băran, Hidro-Gazo-Dinamica Sistemelor de aerare echipate cu generatoare de bule, Editura POLITEHNICA PRESS, Bucureşti, 2009.

[7] G. Oprina, Contribuţii la hidro-gazo-dinamica difuzoarelor poroase, Teză de doctorat, Universitatea Politehnica din Bucureşti, Facultatea de Energetică, 2007.

[8] Rareş Păun, Nicolae Băran, Albertino Giovani Roza, E. Beatrice Tănase, Rasha Cusma "The Use of Microtechnologies Processing on Water Aeration Plants Construction”, International Journal of Mechatronics and Applied Mechanics, 2017, Issue 1, pp 188-192.

[9] Nicolae Băran, George Marin, Mihaela Constantin, Rareş Păun, Albertino Giovani Roza, "Researches on the Use of Air Filtration Element in the Creation of Microbubbles for Water Oxygenation", International Journal of Mechatronic and Applied Mechanics, 2017, Issue 1, pp 184-187. 
[10] R. Păun, Cercetări privind utilizarea concentratoarelor de oxigen la oxigenarea apelor, Teză de doctorat, Universitatea Politehnica din Bucureşti, Facultatea de Inginerie Mecanică și Mecatronică, 2019.

[11] Rareș Păun, Octavian Donțu, Dorina Nicoleta Albu, Nicolae Vlad Sima, Corina Ioana Moga, Elena Beatrice Tănase, "Researches on the use of oxygen concentrators in wastewater oxygenation", International Journal of Mechatronics and Applied Mechanics, 2019.

[12] Roza Giovani Albertino, Cercetări privind utilizarea ozonului la oxigenarea apelor, Teză de doctorat, Universitatea Politehnica din Bucureşti, Facultatea de Inginerie Mecanică și Mecatronică, 2019.

[13] C. Pătru, Folosirea ozonului în tratarea apei, Hidrotehnica, iunie, 1993.

[14] B. Boisselier - Le traitment par l'oxydation avancée optimisée des effluents liquides par l'oxygéne, le péroxyde d'hydrogéne ou l'ozone L'eau, l'industrie et les nuisances, sept. 1993, France.

[15] I. Călușaru, Influenţa proprietăţilor fiziceale lichidului asupra eficienţei proceselor de oxigenare, Teză de doctorat, Universitatea Politehnica din Bucureşti, Facultatea de Inginerie Mecanică și Mecatronică, 2014.

[16] Al. Pătulea, Influența parametrilor funcționali și a arhitecturii generatoarelor de bule fine asupra eficienței instalațiilor de aerare, Teză de doctorat, Universitatea POLITEHNICA din București, 2012.

[17] Albertino Giovani Roza, Nicolae Băran, Mihaela Constantin, Păun Rareş, E. Beatrice Tănase and Adalia Chelmuş "Researches on water aeration", IJISET International Journal of Innovative Science, Engineering \& Technology, Vol. 4, Issue 7, July 2017, ISSN (Online).

[18] Rasha Mlisan, Giovani Roza, Rareș Păun, Nicolae Băran, "Researches on the generation of fine air bubbles required for water aeration process”, Editura AGIR, Revista Termotehnica, Nr. 1/2017, ISSN-L 1222 - 4057, ISSN (Online) $2247-1871$, pp $44-48$. 